POLSKA AKADEMIA NAUK-ZAKŁAD BADANIA SSAKÓW

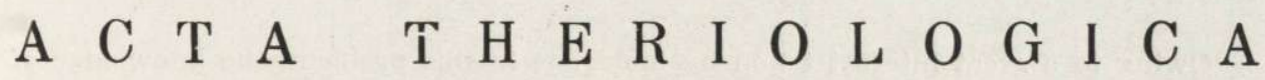
VOL. VII, 17.

\title{
New Colour Mutation (Ruby) \\ in the Microtus arvalis (Pallas, 1779) and Its Inheritance
}

\author{
Nowa mutacja barwna (ruby) \\ u Microtus arvalis (Palla s, 1779) i jej dziedziczność
}

[With 4 Figs. \& 5 Tables]

I. Introduction

II. Course of breeding .

III. Genetic analysis

IV. Discussion

. V. Summary

References

Streszczenie

\section{INTRODUCTION}

The coloration of the back and flank parts of the coat in most mammals living at liberty in Poland is little diversified and as a rule restricted to a narrow range of similar adaptive colours, generally termed agouti. Relatively rarely a coat is more or less variegated, which is caused by differences in pigmentation of some of its portions. In addition, white coloration occurs in some of the Polish mammals in winter.

Occasionally, however, a coat pigmentation shows sudden inheritable changes (mutations), which may produce many colour variations, often very different from the normal. They depend upon the presence of and the quantitative relations between two different pigments: eumelanin, responsible for a range of colours from brown to black and feomelanin, which accounts for the occurrence of colours irom yellow to brown.

Abnormalities in coat coloration in some species of mammals are fairly well known, and particularly so in the case of animals bred in captivity. As regards wild animals, the knowledge of colour mutations of fur is based on casual catches of specimens showing some divergences. Some mutations, however, e.g. the melanic mutation of the hamster Cricetus cricetus ( $\mathrm{L}$ i n $\mathrm{n}$ a e u s, 1758), are not only found in many localities, but also well known in many respects ( $\mathrm{t}$ a c h, 1919; Kuntze \& Szyn a 1, 1933; Kr umbiege l, 1955). 
Owing to a great interest taken by biologists in this problem, the knowledge of colour mutations, as well as the number of nevly recognized mutations in various species of mammals, increases steadily, as shown by many records in literature (S itowski, 1948; Piechocki, 1957; Reichstein, 1957 ; Reichstein \& Kulicke, 1958; Sk oc zeń, 1961). The situation is particularly well illustrated by the example of the common vole Microtus arvalis ( $\mathrm{P}$ a $11 \mathrm{a} \mathrm{s}, 1779$ ), in which only albino and recessive roan mutations were known until recently, and now the number of mutations has risen rapidly to 10 . The descriptions and mentions on the first two mutations are to be found in many works ( $\mathrm{K} \mathrm{untze}, 1930$; M ig uli n, 1938; T urč e k, 1958), while the list of all colour mutations so far known in this species is given by Frank \& Zimmermann (1957).

On 10 October 1958 I received a common vole with a sandy coat, caught in the region of Domasław, $16 \mathrm{~km}$. away from Wrocław. The general appearance of the animal suggested at first that it was a mutation designated as pink-eyed dilution (symbol - p) and found in this species by $\mathrm{S}$ tei n (after Frank \& Z i m m e r m a n n, 1957), but crossing done to get some more mutants showed that, genetically, this specimen was not quite pure, as the mutants obtained in the $\mathrm{F}_{2}$ differed distinctly in coat coloration. The individuals of lighter colour were identified as pink-eyed-dilution mutants (p), those darker in colour could not be identified with any of the known abnormalities in this species, and so they were recognized as a new mutation. This interesting case has made me publish a fairly detailed description of the course of breeding and the genetic analysis of the mutation.

\section{COURSE OF BREEDING}

The common vole caught in the fields of Domasław was a young female, 15.3 g. in weight, in all probability derived from the last September litters, which would indicate that at the time of catching it was about $4-5$ weeks old. The coloration of the dorsal part of its coat was, generally speaking, flavescent (sandy or brown-yellow), closely resembling the colours Verona Brown and Olive Brown according to the scale of $\mathrm{R}$ i $\mathrm{d}$ gw a y $(1912)^{1)}$. The underfur was dark grey. The abdominal part of the coat exhibited a whitish tint with a slight admixture of the dorsal coloration. The eyes of the vole were dark ruby. At the sight of the breeder the animal responded with a rapid escape, alarming other inhabitants of the cage, namely common voles with agouti coats. It struggled desperately while being grasped at, and after being caught it peeped and bit.

It is well known that the common vole does not usually breed in winter ( $\mathrm{S}$ t i e ve, 1923), and for this reason no attempts to mate the mutant were

1) The determination of colours was carried out according to the plates of O s twald (Ostwald \& Streler, 1939), but the names used for colours are those from R i d g w a y's scale ( $\mathrm{Z}$ i m m erm a n n, 1952), 
made at that time. So it was put in a seperate cage, in the company of a somewhat smaller young female of the same species, with which it stayed till 13 March 1959.

The cage was provided with a thick bedding of hay and the voles bred in the laboratory were fed on potatoes, sugar beets, wheat and oats in winter and green crops in summer. Feeding was as a rule done every day (except for some Sundays and holidays), food being always offered in excess. At feeding the animals were subjected to general inspection. They were especially closely watched for the dates of births and the size of litters. To avoid unwanted disturbances the exact number of animals in the particular cages and the number of dead individuals were determined only during the cleaning of the cages, which was usually done once a month. If any of the cages was overcrowded with voles, part of them were moved to other cages.

\section{GENETIC ANALYSIS}

The initial objective of the breeding was to obtain a number of specimens with the changed coloration of hair. For this purpose, on 16 March 1959, the mutant was mated to a relatively well-developed male with an agouti coat characteristic of wild populations of the common vole. This male was also caught as a young individual in the fields of Domasław in the autumn of 1958. For clearness of description the female with a colour mutation of coat will be.referred to as a "flavescent parental female" in the further considerations. The pair was given facilities for begetting three litters, presented in detail in Table 1, so that the mutated character might be transmitted to a number of individuals and the stock preserved, in case the mother or some of $F_{1}$ voles died. The sex distribution in specimens within particular litters, offered in Table 1, is to show further reproductive possibilities of the animals as well as the chance of obtaining specimens with the mutated colour of fur. The disproportion between the numbers of males and those of females is striking. It should, however, be stated beforehand that only a chance may be responsible for this state, and any suspicions as to the presence of a sex-linked lethal gene, which has eliminated some of the males, must be ruled out, for no sharp differences in the numerical relations between both sexes of the animals bred in the laboratory have been found ever since, the number of males being often somewhat larger.

The segregation of characters was watched both in $\mathrm{F}_{1}$ voles (Table 2) and in backcross generations (Table 3 ).

The further reproduction of the voles proceeded within particular litters, the females of the second litter being given one male from the 
Table 1.

List of young voles obtained by crossing flavescent parental female to agouti male.

\begin{tabular}{|c|c|c|c|c|}
\hline \multirow{2}{*}{ Litter } & \multirow{2}{*}{ Date } & \multirow{2}{*}{$\begin{array}{c}\text { Size of } \\
\text { 11tter }\end{array}$} & \multicolumn{2}{|c|}{ No. of asouti voles } \\
\cline { 4 - 5 } & & 5 & 2 & 68 \\
\hline 1. & 17.4 .1959 & 5 & 2 & 3 \\
2. & 12.5 .1959 & 7 & 7 & - \\
3. & 13.6 .1959 & 7 & 3 & 2 \\
\hline 3 & Tota1 & 19 & 14 & 5 \\
\hline
\end{tabular}

\section{Table 2.}

List of litters showing their size and the character of pigmentation in $\mathrm{F}_{2}$ young (agouti $q \times$ agouti $\sigma^{x}$ ).

\begin{tabular}{|c|c|c|c|c|c|}
\hline \multirow[t]{2}{*}{ Litter } & \multirow[t]{2}{*}{ Date } & \multirow{2}{*}{$\begin{array}{l}\text { Size of } \\
\text { litter }\end{array}$} & \multicolumn{2}{|c|}{$\begin{array}{c}\begin{array}{c}\text { Flavescent } \\
\text { voles }\end{array} \\
\end{array}$} & \multirow{2}{*}{$\begin{array}{l}\text { ligout } 1 \\
\text { voles }\end{array}$} \\
\hline & & & Darks & Light & \\
\hline 1. & 27. 7.1959 & 4 & - & 1 & 3 \\
\hline 2. & 31. 7.1959 & 3 & 1 & - & 2 \\
\hline 3. & 7. 8.1959 & 4 & 1 & - & 3 \\
\hline 4. & 18. 9.1959 & 6 & 1 & - & 5 \\
\hline 5. & 28. 9.1959 & 5 & - & 1 & 4 \\
\hline 6. & 22.10 .1959 & 7 & 2 & - & 5 \\
\hline 7. & 2.11 .1959 & 4 & 2 & - & 2 \\
\hline 8. & 5.11 .1959 & 3 & 1 & - & 2 \\
\hline 9. & 11.11 .1959 & 3 & - & - & 3 \\
\hline 10. & 2. 12.1959 & 2 & 1 & - & 1 \\
\hline 11. & 7.12 .1959 & 3 & - & 1 & $2^{\circ}$ \\
\hline 12. & 9.12 .1959 & 5 & - & - & 5 \\
\hline 13. & $22.12,1959$ & 5 & 2 & - & 3 \\
\hline 14. & 16. 1.1960 & 4 & 1 & - & 3 \\
\hline 15. & 21. 1.1960 & 4 & 1 & - & 3 \\
\hline 16. & 5. 2. 1960 & 3 & 1 & - & 2 \\
\hline 17. & 12. 2. 1960 & 3 & 1 & - & 2 \\
\hline 17 & Total & 68 & 15 & 3 & 50 \\
\hline
\end{tabular}

Table 3.

Litters and character of pigmentation of young obtained by backcrossing flavescent parental female to agouti male (from $F_{1}$ ).

\begin{tabular}{|c|c|c|c|c|c|}
\hline \multirow[t]{2}{*}{ Litter } & \multirow[t]{2}{*}{ Date } & \multirow{2}{*}{$\begin{array}{l}\text { Size of } \\
\text { litter }\end{array}$} & \multicolumn{2}{|c|}{$\begin{array}{c}\text { Plavescent } \\
\text { voles }\end{array}$} & \multirow{2}{*}{$\begin{array}{l}\text { Agout1 } \\
\text { voles }\end{array}$} \\
\hline & & & Dark & L1ght & \\
\hline 1. & 8. 8.1959 & 4 & 2 & - & 2 \\
\hline 2. & 17. 9.1959 & 6 & 3 & - & 3 \\
\hline 3. & 21.10 .1959 & 3 & 2 & - & 1 \\
\hline 4. & 17.11 .1959 & 2 & 1 & - & 1 \\
\hline 4 & Total & 15 & 8 & - & 7 \\
\hline
\end{tabular}

third litter only in the autumn, because one male of the first litter (Table 1) died for unknown reasons, the second was left among its sisters, and the third was used for a backcross to the flavescent parental female.

It is noteworthy that reproduction was continued also in autumn and winter. Most of the voles of the three litters mentioned above participated in it. The females of the first litter began to breed first, while those of the second litter were the last to begin breeding and the last to finish it.

Table 2 offers the results of reproduction classified according to pigmentations obtained in the $\mathrm{F}_{2}$. The occurrence of both lighter and darker individuals among the young mutants mendelized was a great surpice. They will be called "light flavescent voles" and "dark flavescent voles". It must be mentioned that the dark flavescent voles appeared in the litters of all the breeding females, while the light flavescent voles were produced by some females from various $F_{1}$ litters. The occurrence of light- and dark-coloured mutants made it necessary to carry out an inheritance check for this character, as described below.

A backcross of an $F_{1}$ male to the flavescent parental female gave 4 litters shown in Table 3. The mutants obtained were dark flavescent. The flavescent paren- 
tal female died soon after delivering the last litter ( $8 \mathrm{Jan} .1960$ ), having lived about 480 days.

In the spring of 1960 all the mutants were seperated from the agouti individuals and bred seperately. Most of their offspring were of the darker colour and towards the end of July 1960 there were only 19 light flavescent voles against 97 dark flavescent ones.

In the second half of 1960 and partly in 1961 the inheritance of coat coloration was watched in small isolated groups and the behaviour of this character was studied on selected specimens over a fairly long time.

The results of the inheritance check for coat coloration in a group of 13 litters of dark flavescent voles produced by 5 females and 3 males are given in Table 4 . The parental animals were kept in two cages: 3 females and 2 males in one cage and 2 females and a male in the other. The growing-up young were moved to other cages. Besides a very large number of dark flavescent voles there also occurred light flavescent individuals. The latter were born in the cage with a large number of parental animals, probably from one female, which, however, I failed to check.

Table 5 shows the litters obtained from the light flavescent voles. They are derived from 3 females and 2 males kept in one cage all through the experiment. As will be seen from the table, the coat colour in the offspring is light flavescent, the same as in their parents.

\section{DISCUSSION}

Mutant voles of two different coat colours were obtained as a result of the crosses described. This phenomenon could not be interpreted as individual colour variation, because both shades of these forms had distinct 


\section{I}

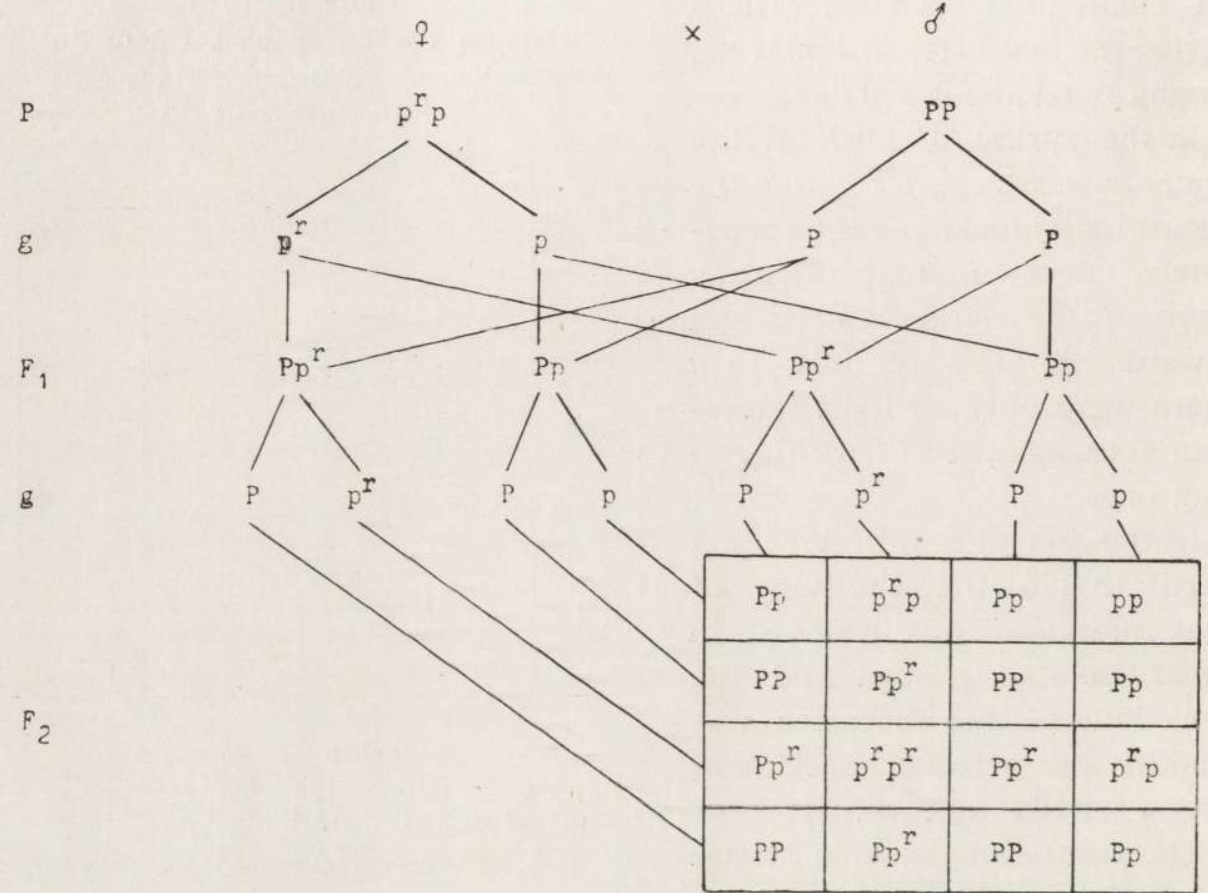

I I

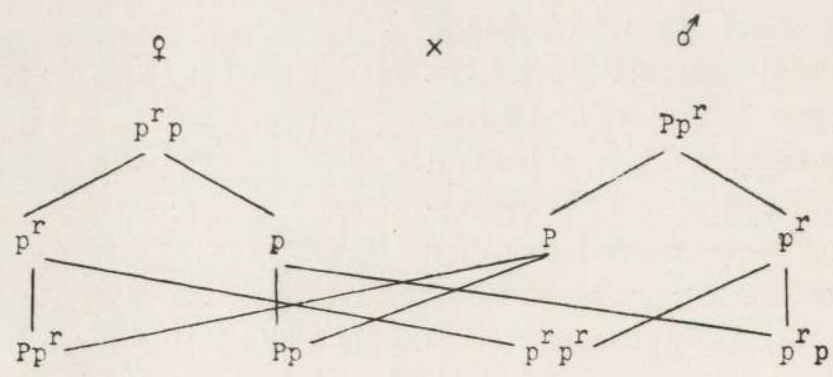

IV
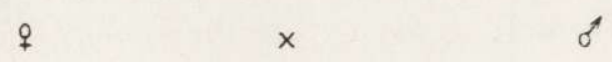

P

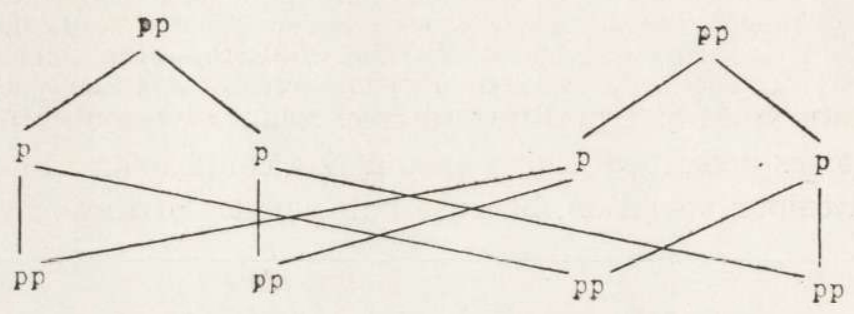


A

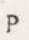
g

$=$

B

$P$

$g$

$F_{1}$

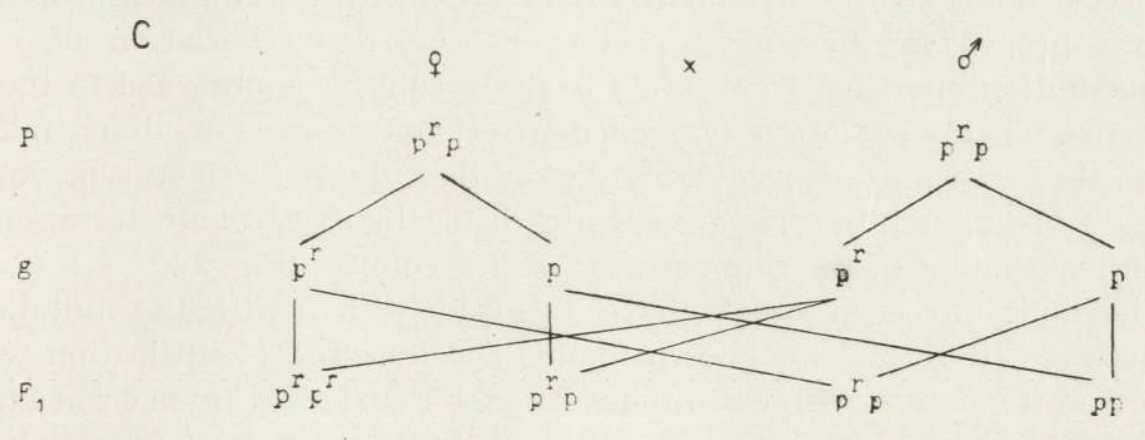

Fig. 3. Diagram of genetic analysis.

I. First phase of genetic analysis including Mendelian segregation of mutants in $\mathrm{F}_{2}$ (ref. to Tables 1 and 2). II. Diagram showing the course of the backcross (ref. to Table 3). III. Inheritance check for coat colour in dark-coloured mutants (ref. to Table 4). The letters A), B), and C) denote crosses that may occur within various genotypes. IV. Inheritance check for coat colour in light-coloured mutants (ref. to Table 5).

Symbols of genotypes and phenotypes proper to them: PP - agouti, Ppr - agouti, $\mathrm{Pp}$ - agouti, $\mathrm{pr}^{\mathrm{r}} \mathrm{-}$ - dark flavescent, prp - dark flavescent, $\mathrm{pp}$ - light flavescent. 
and sharp boundaries (Figs. 1 and 2). It turned out that the twofold pigmentation did not vary with season or age of individuals, but was an inherited character. It was easily recognizable in the first coat of the young, in both cases being somewhat darker than in adults, and was permanently attached to a given individual. The progeny of the light flavescent voles were always like their parents, while the darker mutants produced litters either of darker or of two-coloured individuals, i.e., those of darker and lighter coat coloration. This indicates that, genetically, part of the parents of the dark flavescent voles were not pure for the character in question.

A curious transient variation of coloration, particularly in the dark mutants, was observed at the time of moult. This fact, however interesting on account of a possibility of watching the course of moulting in living animals, has no essential relations with the problem under study.

The colour of the dorsal part of the coat in the light flavescent voles approximates to Vinaceous Buff, Pinkish Cinnamon, and even Japan Rose of the scale of $\mathrm{R}$ i d g w a y (1912). The corresponding colours in the plate of B o $\mathrm{nd} \mathrm{a} \mathrm{r} \mathrm{c} \mathrm{e} \mathrm{v} \mathrm{(1954)} \mathrm{are} \mathrm{approximately} \mathrm{m}_{1}$ and $l_{7}$, i.e., saturate fumosus and arenicolor. The abdominal part of the coat has a lighter coloration with a whitish tint. The eyes of these forms are ruby.

The pigmentation of the dorsal hair in the dark flavescent voles falls more or less within the limits Verona Brown - Olive Brown, and even Bister - Olive Brown (R i d g w a y, 1912). In B ond a r c e v's plate the colours that resemble it most are $\mathrm{n}_{1}$ - olivaceo-griseus and $\mathrm{p}_{1}$ - olivaceus. The coloration on the abdomen is light grey with an admixture of the colour proper to the dorsal portion of fur. Some variation of eye pigmentation, passing from pink to dark ruby, was observed in these mutants. Their eyes often resembled in colour the eyes of albino mice. Thus these voles are considerably darker than the light flavescent voles (Figs. 1 and 2) and, in some cases, little differ in coat colour from some agouti specimens of the common vole of this country (Fig. 2).

The light flavescent voles have been identified with the mutation "pink-eyed dilution" (p) known in this species. The identification was based on the data presented in the work of $\mathrm{Frank} \& \mathrm{Z}$ i m m e r m a n $\mathrm{n}$ (1957). There is hardly any probability that it was another colour mutation with the same phenotype.

I regard the dark flavescent vole as a new colour mutation in this species. It corresponds to the ruby mutation $\left(\mathrm{p}^{\mathrm{r}}\right)$ in Japanese waltzers described by S ô \& I m a i (after G r ü n e b e r g, 1943) in 1926. According to this description ( $\mathrm{Gr} \ddot{\mathrm{u} n}$ e be r g, 1943) the gene $\mathrm{p}^{r}$ acts on the hair coloration of the mouse similarly to the gene $\mathrm{p}$ but less distinctly. On the other hand, the eyes of this mutation may vary from pink to almost black, 
with occasional differences in particular specimens (heterochromia iridis) The dark flavescent mutation is in the same relation to the pink-eyed dilution in the common vole as, according to Gr ün e berg (1943), the ruby mutation to the pink-eyed dilution in the mouse. It is noted for smaller reduction of pigment, shows variation of eye pigmentation, and above all is dominant to the pink-eyed dilution.

Te results of the crosses of flavescent voles to those with agouti coloration indicate the thorough dominance of the latter and the simple Mendelian segregation of the character of pigmentation in the $\mathrm{F}_{2}$ (Tables 2 and 3). This is also true of the dominance and segregation in both mutations discussed. The dark flavescent pigmentation is dominant to the pink-eyed dilution (light flavescent). The conclusion concerning the segregation is based on the data from a few litters (1,6 and 11) given in Table 4. Some deviation from the simple Mendelian ratio, found totally for the whole stock at the end of July 1960, will be discussed later. It may be assumed that both flavescent mutations under study are allelic. The facts mentioned above allow me to recognize the dark flavescent mutation in the common vole as homologous to the ruby mutation in the mouse (S ô \& I m a i, after G r üne ber g, 1943). For this reason I adopt the same denomination and symbol (ruby $-\mathrm{p}^{\mathrm{r}}$ ) for it. It is the fourth mutation in addition to the albino (c), pink-eyed dilution (p), and ivory (i) in Microtus arvalis ( $\mathrm{P}$ a 11 a s, 1779) with a red tint of eyes.

Therefore, a series of multiple allelomorphes with the order of dominance $\mathrm{P}>\mathrm{p}^{\mathrm{r}}>\mathrm{p}$ found in the mouse exists also in the common vole.

In the laboratory the individuals with darker pigmentation out numbered the others mostly because the gene $\mathrm{p}^{\mathrm{r}}$ is dominant to the gene $\mathrm{p}$. They included both homozygous $\left(\mathrm{p}^{\mathrm{r}} / \mathrm{p}^{\mathrm{r}}\right)$ and heterozygous $\left(\mathrm{p}^{\mathrm{r}} / \mathrm{p}\right)$ animals. The whole genetic analysis is shown in Fig. 3, from which it will be seen that the $F_{1}$ individuals constituted two different heterozygous genotypes. Their uniform coloration did not differ from that of wild voles which on account of their grey abdomens are described as grey-bellied agouti voles. Besides, two other phenotypes of mutants were mendelized in the next generation. If all possible combinations of alleles were present, the three phenotypes obtained in the $\mathrm{F}_{2}$ represented six different genotypes. As mentioned above, the general relation of the agouti voles to all the flavescent mutants of the $\mathrm{F}_{2}$ agreed with $\mathrm{M}$ e $\mathrm{ndel}$ l's laws. The proportion of the pink-eyed-dilution mutants to the ruby ones was, as shown in Table 2, somewhat smaller than the value calculated from the rule of inheritance (Fig. 3). The vitiation of the picture was due to the action of casual factors, such as the genotypical character of voles participating in reproduction and the size of litters. The same is true of the numbers of different mutants found at the end of July 1960. 
Then the genetic analysis showed that the mutant taken in the fields of Domasław was an interesting heterozygote, from which two groups of voles differing in colour were mendelized in the laboratory. It is less probable, though not impossible, that one of these mutations (pink-eyed dilution) came into existence in captivity. Also the derivation of one of the mutations from the male of the $\mathrm{P}$ generation (Table 1) must be ruled out, because after being seperated from the flavescent parental female it was mated to two agouti females and, which must be emphasized, none of their about $20-30$ offspring $\left(\mathrm{F}_{2}, \mathrm{~F}_{3}, \mathrm{~F}_{4}\right)$ kept for a relatively long time showed any abnormality in coat coloration. Both this fact and the uniform coloration of $\mathrm{F}_{1}$ individuals (Table 1 ) prove that this male was a homozygote for the agouti coloration $\left(\mathrm{A}^{+} / \mathrm{A}^{+}\right)$and as such could not pass a gene responsible for a colour abnormality to its progeny.

There being a great abundance of common voles then, the time was favourable for the occurrence of such a set of alleles in the flavescent parental female and its taking the form of the phenotype described. It is the only case of a colour mutation involving the whole coat so far found by me among about 5000 specimens of this species. Voles with larger or smaller white spots on their agouti-coloured coats were met with more frequently. In most cases the spots were situated on the head. About $10 \%$ of the specimens of Microtus arvalis ( $\mathrm{Pa} 1 \mathrm{la}$ s, 1779) kept in captivity in the years 1958-1959 showed this roan mutation.

Finally, it must be added that the rate of development in young voles of the new mutation here described did not differ from that in agouti voles. Valuation in this respect was, however, done only visually. I shall deal with this problem and some other questions in the future, if I manage to maintain the stock. I must mention that now it shows a serious decline caused undoubtedly by inbreeding. It has been found that there is an apparent drop in number and size of litters, which do not usually exceed $2-3$ individuals. In the close future I intend to increase the viability of the stock by crossing part of individuals to agouti voles collected in natural environment and obtaining new mutants according to the Mendelian rule of segregation.

\section{SUMMARY}

The author presents a description of a flavescent mutant of the common vole Microtus arvalis (P a 11 as, 1779) caught near Wrocław on 18 October 1958, followed by an account of the course and results of the genetic analysis concerning this mutant. The analysis showed that it was a heterozygote for coat coloration. Two kinds of fur pigmentation occurred among the mutants obtained from Mendelian segregation, a lighter one, corresponding to the mutation pink-eyed dilution known 
earlier in this species, and a darker one. This last mutation was identified with the colour mutation ruby $(\mathrm{pr})$ described in Japanese waltzers. Consequently, the same denomination and symbol were adopted. It appeared to be a new coldur mutation hitherto unknown in the common vole.

\section{REFERENCES}

1. B o nd a r cev, A. S., 1954: Skala cvetov. Izdat. Akad. Nauk SSSR, Moskva-Leningrad.

2. Frank, F. \& Z i m m e r m a n n, K., 1957: Färbungs-Mutationen der Feldmaus, Microtus arvalis (P a 11.). Ztschr. Säugetierkde, 22, 1-2: 87-100. Berlin-Dahlem.

3. Grüneberg, H., 1943: The Genetics of the Mouse. University Press, Cambridge.

4. Krumbiege 1, I., 1955: Biologie der Säugetiere. Agis-Verlag, Krefeld und Baden-Baden.

5. K u n tze, R., 1930: Przyczynek do znajomości fauny ssaków południowej Polski. Kosmos „A", 55, 1-2: 219-232. Lwów.

6. K u n t z e, R. \& S z y n a 1, E., 1933: Przyczynek do znaojmości fauny ssaków Polski. Kosmos „A", 58, 1-4: 77 .

7. (M i g u li n, O. O.), 1938: Zviri URSR. Vyd. Akad. Nauk URSR, Kjiv.

8. Piechocki, R., 1957: Färbungs-Mutation der Zwergmaus (Micromys minutus $P$ a 11.). Ztschr. Säugetierkde, 22, 1-2: 106. Berlin-Dahlem.

9. Reichstein, H., 1957: „Schwarz” eine neue Mutation bei Microtus arvalis (P a 11.). Ztschr. Säugetierkde, 22, 1-2: 102-703. Berlin-Dahlem.

10. Reichstein, H. \& Kulicke, H., 1958: Elfenbein, eine neue Farbmutante bei der Rötelmaus, Clethrionomys glareolus S c h r e b. Ztschr. Säugetierkde, 23, 1-2: 115. Berlin-Dahlem.

11. Sitowski, L., 1948: Przyczynek do znajomości fauny Parku Narodowego w Pieninach. Ochr. Przyrody, 18: 133-142.

12. S k o c z e ń, S., 1961: Colour mutations in the mole, Talpa europaea L in n a e u s, 1758. Acta theriol., 5, 20: 290-293. Białowieża.

13. Sta ch, J., 1919: Uber die schwarze Morphe des Hamsters, „Cricetus cricetus L. m. niger". (Beitrag zur Frage der Fixierung von abgeänderten Formen und zur Verbreitung des Hamsters). Bull. Intern. Acad. Pol. Sci. et Lettr., Cl. Sci. Math. et Nat., Ser. B, No. 1-4: 1-9. Kraków.

14. Stach, J., 1920: O czarnej odmianie chomika Cricetus cricetus L. m. niger. Rozpr. Wydz. Mat.-Przyr. PAU, B (19/59) [1919]: 43-96. Kraków.

15. S ti e ve, H., 1923: Untersuchungen über Wechselbeziehungen zwischen Gesamitkörper und Keimdrüsen. Arch. mikr. Anat., 99: 390-570.

16. T u r č e k, F. J., 1958: Albinistische Feldmaus (Microtus arvalis incognitus). Säugetierkdl. Mitt., 6: 30 .

17. Zimmermann, K., 1952: Vergleichende Farbtabellen. Ridgway-Ostwald, Ostwald-Ridgway. P. Schöps Verl., Frankfurt/M.

College of Agriculture,

Department of Zoology,

Wrocław, Cybulskiego 20. 


\section{STRESZCZENIE}

W pracy przedstawiono opis złowionego w dniu 18.X.1958 r. pod Wrocławiem flawistycznego mutanta nornika zwyczajnego, Microtus arvalis (P a llas, 1779) oraz przebieg i wyniki analizy genetycznej. Wykazała ona, że osobnik ten był ze względu na ubarwienie futerka heterozygotą. Wśród wymendlowanych mutantów wystạpiły dwa rodzaje pigmentacji uwłosienia, jaśniejsza odpowiadająca znanej u tego gatun$\mathrm{ku}$ mutacji pink-eyed dilution oraz ciemniejsza. Tę ostatnią utożsamiono $\mathrm{z}$ opisaną u japońskich myszy tańczących mutacją barwną ruby $\left(\mathrm{p}^{\mathrm{r}}\right)$. Przyjęto więc tę samą nazwę i symbol. Okazała się ona nową nieznaną dotychczas u nornika zwyczajnegc mutacją barwną.

\section{EXPLANATION OF PLATE XXIX.}

Phot. 1. Two colour mutations of the common vole. The lighter individual shows the mutation pink-eyed dilution, the darker one the ruby.

Phot. 2. Three differently pigmented furs of the common vole. A - full colour, $\mathrm{B}$ - pink-eyed dilution, C - ruby. 

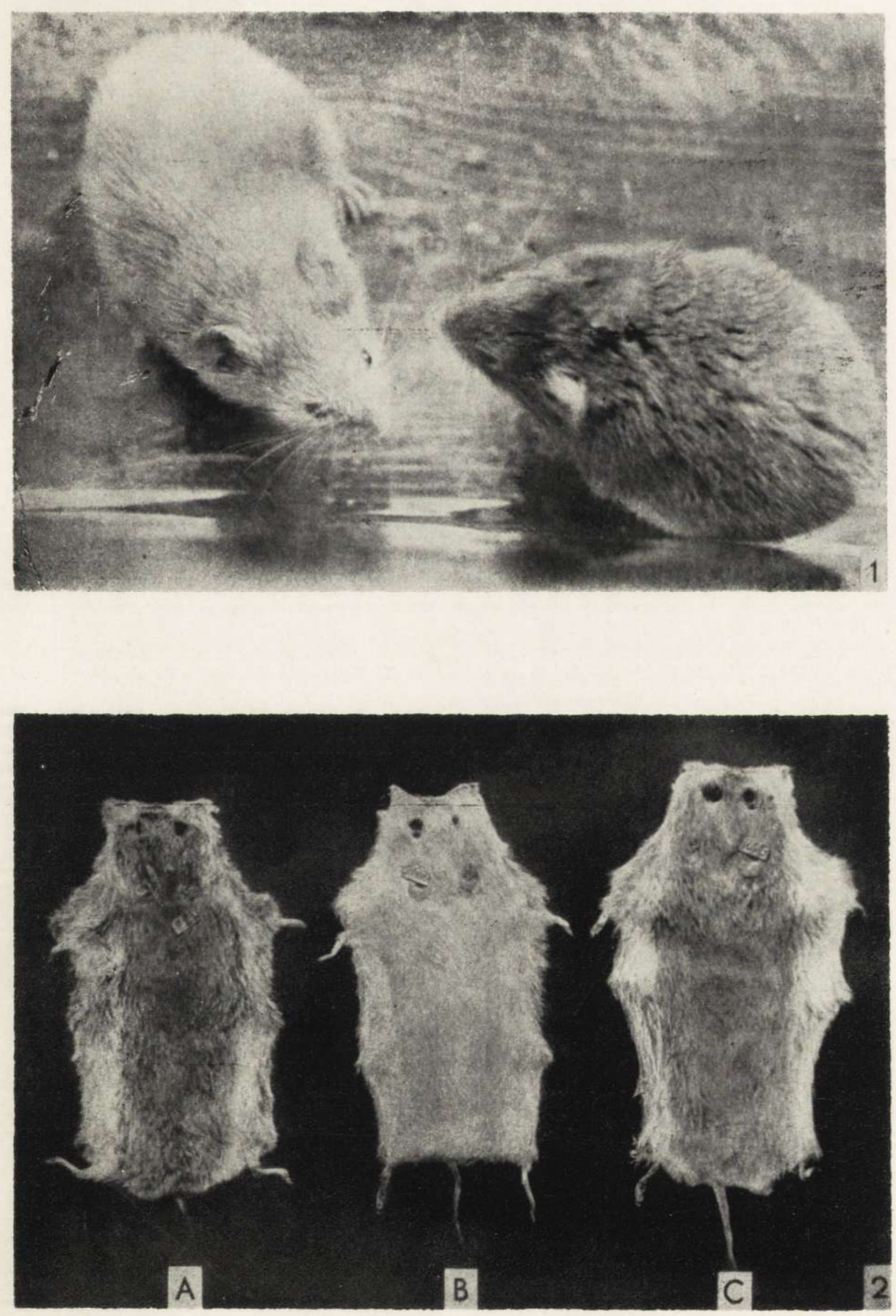

S. Humiński

auctor phot. 
BIBLIOTEKA

Instytutu Biologii Ssaków

Polskiej Akademii Nauk

$\mathrm{NrCz} .40 .2$ 